Louisiana State University

LSU Digital Commons

Faculty Publications

Department of Biological Sciences

$1-1-2017$

\title{
The biogeography of sodium in Neotropical figs (Moraceae)
}

Adriana Bravo

American Museum of Natural History

Kyle E. Harms

Louisiana State University

Follow this and additional works at: https://digitalcommons.Isu.edu/biosci_pubs

\section{Recommended Citation}

Bravo, A., \& Harms, K. (2017). The biogeography of sodium in Neotropical figs (Moraceae). Biotropica, 49 (1), 18-22. https://doi.org/10.1111/btp.12398

This Article is brought to you for free and open access by the Department of Biological Sciences at LSU Digital Commons. It has been accepted for inclusion in Faculty Publications by an authorized administrator of LSU Digital Commons. For more information, please contact ir@lsu.edu. 
INSIGHTS

\title{
The biogeography of sodium in Neotropical figs (Moraceae)
}

\author{
Adriana Bravo ${ }^{1,3}$, and Kyle E. Harms ${ }^{2}$ \\ ${ }^{1}$ Center for Biodiversity and Conservation, American Museum of Natural History, Central Park West at 79th street, New York, NY 10024, \\ USA
}

${ }^{2}$ Department of Biological Sciences, Louisiana State University, 202 Life Sciences Bldg., Baton Rouge, LA 70803, USA

\section{ABSTRACT}

Sodium is essential for animals but not for most plants. Terrestrial sodium comes largely from marine aerosols, so inland ecosystems should have greater potential for sodium limitation than coastal ecosystems. We report a significant decrease of sodium in fruits of four Neotropical Ficus species with distance from presumed marine source.

Abstract in Spanish is available with online material.

Key words: Amazonia; collpas; Ficus; geophagy; mineral licks; Neotropics; salt.

SODIUM IS AN ESSENTIAL NUTRIENT FOR ANIMALS. It plays a critical role in the physiology of osmoregulation, nerve impulses and muscular function (Michell 1995). Owing in part to its importance, sodium is one of the most limiting nutrients to animals and microbes in the mid-continental Neotropics (Stark 1970, Emmons \& Stark 1979, Brightsmith et al. 2008, Kaspari et al. 2008, Powell et al. 2009, Dudley et al. 2012). The heterogeneous geographic availability of sodium should have substantial consequences for animal assemblages and whole ecosystems (Kaspari et al. 2008, 2009).

In contrast to animals, most terrestrial plants do not require sodium, and in high concentrations it can be toxic (Maathuis 2014). The extent to which plants take up sodium from the soil varies across species and may also depend on soil concentrations of other nutrients, such as potassium (Subbarao et al. 2003). However, within the sodium-tolerance range, sodium concentrations found in plant tissues are expected to reflect soil (or growth-medium) concentrations of sodium (Maathuis 2014).

Sodium availability is geographically patterned (Cheeseman 2015). Most sodium input to terrestrial ecosystems comes from aerosol deposition from marine sources, and therefore sodium input decreases sharply with increasing distance from the ocean (Stallard \& Edmond 1981). As a consequence, ecosystems far from the ocean should have greater potential for sodium to limit organisms compared to ecosystems in coastal areas. Inland areas are expected to have lower sodium concentrations in soils, leading to lower sodium concentrations in plants, and consequently providing limited sodium to herbivorous and frugivorous consumers (Stark 1970, Jordan \& Herrera 1981).

Animal behaviors suggesting sodium-limited diets have been documented in Neotropical areas distant from the ocean. For instance, herbivorous ants had a stronger preference for higher

Received 29 March 2016; revision accepted 8 July 2016.

${ }^{3}$ Corresponding author; e-mail: adrianabravo1@gmail.com concentrations of sodium in western Amazonia compared to Panama, and an overall higher preference for sodium over sucrose compared to carnivorous ants (Kaspari et al. 2008). Similarly, in western Amazonia several species of mammals and birds that feed primarily on plants visit unusual, sodium-rich soil patches along the riverbanks or forest interior-known as collpas, clay licks or mineral licks - to consume soil (Emmons \& Stark 1979, Brightsmith \& Aramburú Muñoz-Najar 2004, Bravo et al. 2008, 2010, Lee et al. 2010, Powell et al. 2009, Tobler et al. 2009, Blake et al. 2011). In contrast, there are no records of strictly carnivorous species consuming soil in these areas, presumably because carnivores obtain sufficient sodium from their animal prey.

Along with the accumulating evidence for sodium limitation among primary consumers in regions distant from the ocean, an important question is whether low sodium availability in the physical environment is reflected in the plants consumed by herbivores. In a study on the use of mineral licks by frugivorous bats in the Peruvian Amazon, Bravo et al. (2012) reported significantly lower concentrations of sodium in figs compared to those from Barro Colorado Island in Panama, as previously reported by Wendeln et al. (2000). To our knowledge there are no studies that have systematically assessed the biogeographic patterns of sodium concentration in plants.

We assessed the patterns of sodium concentrations in the syconia (i.e., the fruits) of four Ficus species that occur broadly throughout the Neotropics. We used Ficus as a study group because of its importance as a keystone resource for the community of vertebrates (Terborgh 1986). In the Neotropics, figs are produced asynchronously year-round, providing a reliable resource for several vertebrate species (Milton et al. 1982, Terborgh 1986). Figs have been recorded as the main dietary components of numerous species of birds (Snow 1981), monkeys (Milton et al. 1982, Terborgh 1983), and bats (Morrison 1978, Giannini \& Kalko 2004, Lobova et al. 2009, Bravo et al. 2012). 
Coincidently, several of these and other largely frugivorous species, such as the lowland tapir, white-lipped peccary, red-brocket deer, spider monkey, wholly monkey, guans, parrots, and frugivorous bats, among others, have also been observed consuming sodium-rich soil in areas far from the ocean (Emmons \& Stark 1979, Brightsmith \& Aramburú Muñoz-Najar 2004, Bravo et al. 2008, Tobler et al. 2009, Blake et al. 2011).

We collected dried syconia (figs) of four Ficus species from 158 specimens of the herbarium collections of the New York Botanical Garden (NYBG) in New York, NY and the Missouri Botanical Garden (MBG) in Saint Louis, MO. We sampled 58 specimens of Ficus citrifolia, 34 of Ficus insipida, 56 of Ficus maxima, and 10 of Ficus paraensis (see Table S1). To avoid unnecessary destruction of herbarium specimens, we sampled whole figs preserved in paper envelopes as part of the specimen, did not remove figs that were attached to the vegetative parts of the specimen, and only sampled specimens with enough figs to remain with a sample after collection. We collected $\sim 0.5 \mathrm{~g}$ of dry mass (one or two figs) using a one-gram Pesola scale. We placed the samples in a labeled paper coin envelope and took a picture of the voucher specimen to record specimen data. The geographic distribution of the samples ranged in latitude from $\sim 21^{\circ}$ $\mathrm{N}$ to $\sim 57^{\circ} \mathrm{S}$, as shown in Fig. 1. For this study, we added two samples each from F. insipida and F. maxima from a previous study (Bravo et al. 2012) to complete a total of 162 data points.

The sodium concentration on a dry mass basis of each fig sample, including those from Bravo et al. (2012), was determined at the Soil Testing and Plant Analysis Laboratory at the Louisiana State University Agricultural Center (http://www.lsuagcenter. com). First, $5 \mathrm{ml}$ of concentrated $\mathrm{HNO}_{3}$ was added to a minimum of $0.5 \mathrm{~g}$ ground, dry plant matter. After $50 \mathrm{~min}, 3 \mathrm{ml}$ of

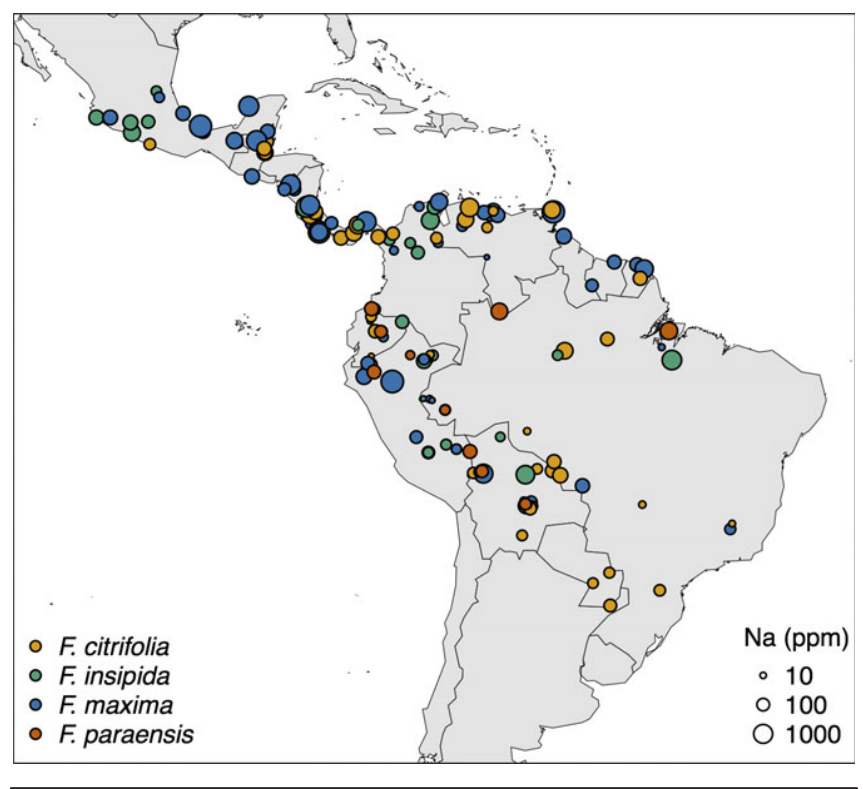

FIGURE 1. Geographic locations and sodium concentrations (ppm) of Ficus fruits from herbaria, sampled across the Neotropics. Circle size indicates sodium concentration.
$\mathrm{H}_{2} \mathrm{O}_{2}$ was added and the sample was digested on a heat block for 2.75 h. Finally, samples were cooled and diluted to measure the concentration of minerals using inductively coupled plasma spectrometry. Concentrations were provided in parts per million (ppm). Concentrations of aluminum, boron, calcium, copper, iron, magnesium, manganese, phosphorus, potassium, sulfur, and zinc were also provided by the lab (Table S1).

To determine the distance of the sampled figs to the closest effective source of sodium, we first plotted the location of each sample on a map. We then measured the distance $(\mathrm{km})$ to the closest marine coast, or, if a mountain barrier ( $>2000 \mathrm{~m}$ asl) blocked the shortest path to the sea, to the closest coast not blocked by a mountain barrier. We assigned geographic coordinates in the Universal Transverse Mercator (UTM) system to each fig sample by using the location information from the vouchers and then plotted these points on a map using the maptools library in R (R Development Core Team, 2012). Using this map as a reference, we located each sample point in Google Earth (http://www.google.com/earth/) and estimated its closest distance to the ocean. For the Amazon region, we followed Stallard and Edmond (1981) by using the Atlantic coast as the region's source of sodium since the Andes Cordillera constitutes a geographic barrier to the aerosols of the Pacific Ocean.

To determine if distance to the nearest effective source of sodium predicts sodium concentration in Ficus fruits, we built four Generalized Least Squares models including two that accounted for spatial autocorrelations (Gaussian and exponential correlation structure). We compared all models using the Akaike Information Criteria (AIC, Burnham \& Anderson 2002) and calculated the pseudo R-square for the fittest model (Nagelkerke 1991). We also explored the responses of the other eleven elements to the same distances (Table S1). All analyses were conducted in R ( R Development Core Team, 2012). We did not include the collection year of each specimen as a covariate in the model, since we found no correlation between this variable and sodium concentration in figs.

Sodium concentration in figs decreased as a function of the effective distance to the ocean (Fig. 2). Based on the model selection, distance to the nearest effective marine source is the best explanatory variable for the concentrations found in four Ficus species (pseudo $R^{2}=0.22$; Table 1 ). Adding species identity or spatial autocorrelation to the models did not improve model support (Table 1). In the case of the other eleven elements, only three (Bo, $\mathrm{Ca}$, and $\mathrm{Mn}$ ) showed significant variation with distance, but in all cases the variation was of a much lower magnitude than that of sodium (Fig. S1; Table S2).

We found that sodium concentration in Ficus fruits (figs) decreased as a function of the distance to the nearest effective marine source of sodium. This pattern supports one prediction of the geographic sodium limitation hypothesis, that is, a decrease in plant-tissue concentrations with increasing effective distance from the sea (Stallard \& Edmond 1981, Kaspari et al. 2008). Similar to our findings, Bravo et al. (2012) found that the sodium concentrations in fruits of Ficus species from southeastern Peru were significantly and substantially (by two orders of magnitude) 

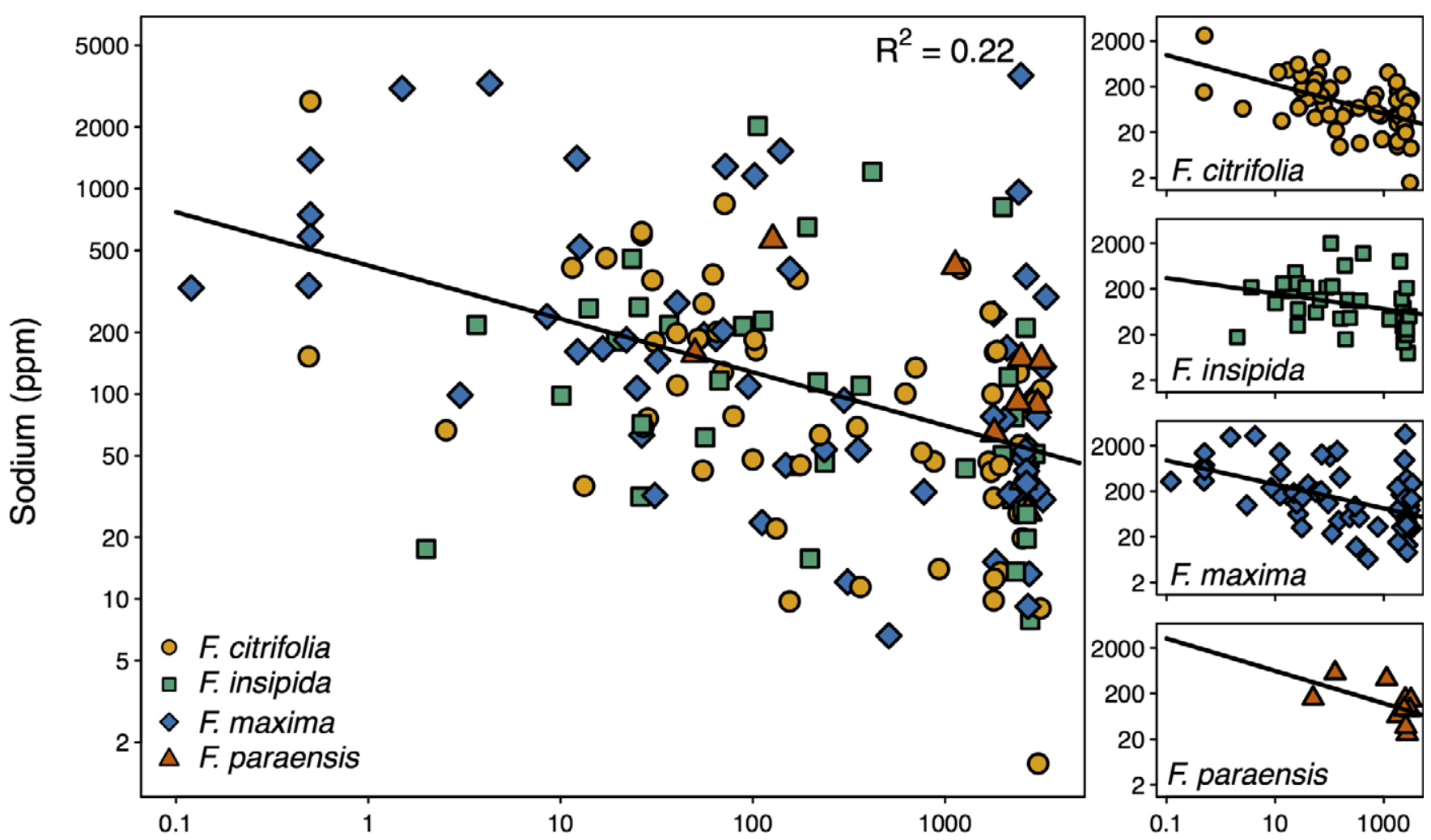

\section{Distance to nearest effective source of marine sodium $(\mathrm{km})$}

FIGURE 2. Sodium concentration (ppm) in fruits relative to the nearest effective source of marine sodium (km) (i.e., nearest ocean not blocked by a mountain chain) in four Neotropical Ficus species. Pseudo $R^{2}$ value is provided.

TABLE 1. Models and model-selection statistics for the relationship between sodium concentration in fruits of four Ficus species and distance to the nearest effective source of marine sodium.

\begin{tabular}{lcccc}
\hline Model & $\operatorname{logLik}$ & AIC & $\Delta$ AIC & $\omega$ \\
\hline Constant & -282.9 & 569.8 & 36.6 & 0.00 \\
$\log$ (Distance) & -263.6 & 533.2 & 0 & 0.32 \\
$\log$ (Distance) + Species & -260.9 & 533.7 & 0.5 & 0.25 \\
$\log$ (Distance) + Species & -259.8 & 533.5 & 0.3 & 0.27 \\
$\quad$ (Gaussian autocorrelation) & & & & \\
$\log$ (Distance) + Species & -260.2 & 534.5 & 1.3 & 0.17 \\
$\quad$ (Exponential autocorrelation) & & & & \\
\hline
\end{tabular}

$\log$-Lik $=$ logarithm of the maximized likelihood; AIC $=$ Akaike Information Criterion; $\triangle \mathrm{AIC}=$ difference in $\mathrm{AIC}$ values between a model and the best model; $\omega=$ model probability.

lower than those from Ficus species found in Panama (Wendeln et al. 2000). Together, these observations suggest that sodium availability in the fruits of keystone species such as Ficus species is strongly influenced by the geographic distribution of sodium inputs into Neotropical ecosystems.
The limited availability of sodium in fruits of multiple Ficus species in inland regions in the Neotropics, such as western Amazonia, suggests that concentrations in other tissues and other plant species in this region may also be low. For instance, Gilardi (1996) reported an average sodium concentration of $38.8 \pm 11.3 \mathrm{ppm}$ for various parts of 50 plant species (including fruits of eight Ficus species) consumed by parrots in southeastern Peru. Later, Brightsmith et al. (2008) reported similar findings for 12 other plant species. As a consequence, plant-eating animals in inland Amazonia potentially face sodium limitation in their primary diets (Gilardi 1996, Brightsmith et al. 2008), which may explain the use of secondary sources of sodium, such as the licks used by a diversity of primarily herbivorous and frugivorous animal species (Emmons \& Stark 1979, Brightsmith \& Aramburú Muñoz-Najar 2004, Bravo et al. 2008, Brightsmith et al. 2008, Powell et al. 2009, Tobler et al. 2009). Furthermore, although numerous species of herbivores and frugivores have been observed engaging in geophagous behavior (i.e., soil consumption) and drinking sodium-rich water (see Bravo et al. 2012 and references therein), this does not seem to be a common behavior in regions closer to the ocean (Lee et al. 2010).

The biogeographic pattern of sodium in figs reported in this study could have numerous implications for plant-eating animals 
and ecosystems. For instance, studies have shown that herbivorous ants in the western Amazon have a strong preference for sodium-rich solutions compared to other baits (Kaspari et al. 2008, Arcila Hernandez et al. 2012). Similarly, species of phyllostomid bats, ungulates, rodents, primates, birds, and insects in western Amazonia visit sodium-rich licks to consume sodium-rich soil or to drink sodium-rich muddy water from soil depressions made by the excavations of larger geophagous mammals (Bravo et al. 2008, Brightsmith et al. 2008, Lee et al. 2010, Blake et al. 2011). Although no studies have reported the consequences of sodium limitation for Neotropical animals at the population or community levels, the physiological importance of sodium suggests that they could be substantial for absolute and relative population-level phenomena such as local abundances, distribution patterns, and overall population sizes. At the ecosystem level, sodium has been shown to play a critical role in the process of litter decomposition, such that in ecosystems with limited sodium, carbon cycling could be slower relative to sites with greater sodium availability (Kaspari et al. 2009).

The biogeographic pattern of sodium limitation was similar in all species we studied, suggesting that the environmental influence (i.e., soil concentration) is more consequential than species identity or phylogeny. Although there was variation in sodium concentration within sites, we found no significant effect of species identity on the concentration of sodium in figs. These results contrast with a previous report for 14 species of figs on Barro Colorado Island, Panama, but in that case the values varied across a relatively small range of high values, from a minimum of $1050 \mathrm{ppm}$ to a maximum of $2800 \mathrm{ppm}$ (Wendeln et al. 2000).

We tried to thoroughly cover the Neotropics from samples available in two herbaria. Future studies could extend our results with additional herbarium sampling or collection of fresh material, particularly from central Amazonia, for which limited material was found in the herbaria visited in this study. In addition, sampling other species of plants consumed by herbivores and frugivores would provide a test for the generality of these biogeographic patterns and their potential consequences for plant-eating heterotrophs. Another important topic of research is to understand the effects of temporal (e.g., seasonality, year-to-year variability in rainfall/drought) and spatial (e.g., habitat, topography) factors on the availability of sodium in the soil and plant tissues. Detailed information at the local scale and over time would refine our findings and potentially explain additional variation in the sodium concentration of figs. Finally, to fully establish the links between sodium availability in the soil and sodium concentrations in plant tissues (i.e., where sodium becomes available to heterotrophic consumers), we need detailed, coordinated studies of soils and plant tissues, together with sodium-manipulation experiments directed toward all ecosystem components, including animal and microbial consumers.

\section{ACKNOWLEDGMENTS}

We extend our gratitude to Stella Sylva and Barbara Thiers from the New York Botanical Garden and Jim Solomon from the
Missouri Botanical Garden for providing permits and facilitating access to herbarium Ficus samples. We thank Santiago Claramunt and two anonymous reviewers for their comments on the manuscript, Louise Emmons for her feedback on previous research that led to this study, and Maheshi Dassanayake, Fern Galvez, and Jennifer Powers for helpful suggestions. This research received funding from LSU.

\section{DATA AVAILABILITY}

Data deposited in the Dryad Repository: http://dx.doi.org/ 10.5061/dryad.k5k3n (Bravo \& Harms 2016).

\section{SUPPORTING INFORMATION}

Additional Supporting Information may be found online in the supporting information tab for this article:

FIGURE S1. Concentrations of eleven elements in relation to sodium in fruits of four Ficus species from herbaria, sampled across the Neotropics.

TABLE S1. Models and model-selection statistics for the relationship between the concentrations of 11 elements in fruits of four Ficus species and distance to the nearest effective source of marine sodium.

TABLE S2. Ficus specimen information including distance to an effective marine sodium source and concentration of twelve minerals.

\section{LITERATURE CITED}

Arcila Hernandez, L. M., E. V. Todd, G. A. Miller, and M. E. FrederickSON. 2012. Salt intake in Amazonian ants: too much of a good thing? Insectes Soc. 59: 425-432.

Blake, J. G., D. Mosquera, J. Guerra, B. A. Loiselle, D. Romo, and K. SwING. 2011. Mineral licks as diversity hotspots in lowland forest of eastern Ecuador. Diversity 3: 217-234.

Bravo, A., K. E. Harms, R. D. Stevens, and L. H. Emmons. 2008. Collpas: activity hotspots for frugivorous bats (Phyllostomidae) in the Peruvian Amazon. Biotropica 40: 203-210.

Bravo, A., K. E. Harms, and L. H. Emmons. 2010. Puddles created by geophagous mammals are mineral sources for frugivorous bats (Stenodermatinae) in the Peruvian Amazon. J. Trop. Ecol. 26: 173-184.

Bravo, A., K. E. Harms, and L. H. Emmons. 2012. Keystone resource (Ficus) chemistry explains lick visitation by frugivorous bats. J. Mammal. 93: 1099-1109.

Bravo, A., AND K. E. Harms. 2016. Data from: the biogeography of sodium in Neotropical figs (Moraceae). Dryad Digital Repository. doi:10.5061/ dryad.k $5 \mathrm{k} 3 \mathrm{n}$

Brightsmith, D. J., And R. Aramburú Muñoz-Najar. 2004. Avian geophagy and soil characteristics in southern Peru. Biotropica 36: 534-546.

Brightsmith, D. J., J. Taylor, and T. D. Phillips. 2008. The roles of soil characteristics and toxin adsorption in avian geophagy. Biotropica 40: 766-774.

Burnham, K. P., And D. R. Anderson. 2002. Model selection and multimodel inference: a practical information-theoretic approach. Springer, New York, NY.

Cheeseman, J. M. 2015. The evolution of halophytes, glycophytes and crops, and its implications for food security under saline conditions. New Phytol. 206: 557-570.

Dudiey, R., M. Kaspari, and S. P. Yanoviak. 2012. Lust for salt in the western Amazon. Biotropica 44: 6-9. 
Emmons, L. H., AND N. M. StARK. 1979. Elemental composition of a natural mineral lick in Amazonia. Biotropica 4: 311-313.

Gilardi, J. D. 1996. Ecology of Parrots in the Peruvian Amazon: Habitat Use, Nutrition, and Geophagy. PhD Dissertation. University of California, Davis, CA.

Giannini, N. P., And E. K. V. Kalko. 2004. Trophic structure in a large assemblage of phyllostomid bats in Panama. Oikos 105: 209-220.

Jordan, C. F., and R. Herrera. 1981. Tropical rain forests: are nutrients really critical? Am. Nat. 117: 167-180.

Kaspari, M., S. P. Yanoviak, and R. Dudley. 2008. On the biogepgraphy of salt limitation: a study of ant communities. Proc. Natl Acad. Sci. USA 105: $17848-17851$.

Kaspari, M., S. P. Yanoviak, R. Dudley, M. Yuan, and N. A. Clay. 2009. Sodium shortage as a constraint on the carbon cycle in an inland tropical rainforest. Proc. Natl Acad. Sci. USA 106: 19405-19409.

Lee, A. T. S., S. Kumar, D. J. Brightsmith, and S. J. Marsden. 2010. Parrot claylick distribution in South America: do patterns "where" help answer the question "why"? Ecography 33: 503-513.

Lobova, T. A., C. K. Geiselman, and S. A. Mori. 2009. Seed dispersal by bats in the neotropics. New York Botanical Garden Press, New York, NY.

MaAthuis, F. J. M. 2014. Sodium in plants: perception, signaling, and regulation of sodium fluxes. J. Exp. Bot. 65: 849-958.

Michell, A. R. 1995. The clinical biology of sodium: the physiology and pathophysiology of sodium in mammals. Elsevier Science Ltd., New York, NY.

Milton, K., D. M. Windsor, D. W. Morrison, and M. A. Esterbini. 1982. Fruiting phenologies of two tropical Ficus species. Ecology 63: 752-762.

Morrison, D. 1978. Foraging ecology and energetics of the frugivorous bat Artibeus jamaicencis. Ecology 59: 716-723.
Nagelkerke, N. J. D. 1991. A note on a general definition of the coefficient of determination. Biometrika 78: 691-692.

Powell, L. L., T. U. Powell, G. V. N. Powell, and D. J. Brightsmith. 2009. Parrots take it with a grain of salt: available sodium content may drive collpa (clay lick) selection in southeastern Peru. Biotropica 41: 279282.

R Development Core Team. 2012. R: a language and environment for statistical computing. R Foundation for Statistical Computing, Vienna, Austria. http://www.R-project.org.

SNow, D. W. 1981. Tropical frugivorous birds and their food plants: a world survey. Biotropica 13: 1-14.

Stallard, R. F., and J. M. Edmond. 1981. Geochemistry of the Amazon: 1. Precipitation chemistry and the marine contribution to the dissolved load at the time of peak discharge. J. Geophys. Res. 86: 9844-9858.

Stark, N. 1970. The nutrient content of plants and soils from Brazil and Surinam. Biotropica 2: 51-60.

Subbarao, G. V., O. Ito, W. L. Berry, and R. M. Wheeler. 2003. Sodium-a functional plant nutrient. Crit. Rev. Plant Sci. 22: 391-416.

Terborgh, J. 1983. Five new world primates: a study in comparative ecology. Princeton University Press, Princeton, NJ.

Terborgh, J. 1986. Keystone plant resources in the tropical forest. In M. E. Soule (Ed.). Conservation biology: the science of scarcity and diversity, pp. 330-344. Sinauer Associates Inc, Sunderland, MA.

Tobler, M. W., S. E. Carrillo-Percastegui, and G. Powell. 2009. Habitat use, activity patterns and use of mineral licks by five species of ungulate in south-eastern Peru. J. Trop. Ecol. 25: 261-270.

Wendeln, M. C., J. R. Runkie, and E. K. V. Kalko. 2000. Nutritional values of 14 fig species and bat feeding preferences in Panama. Biotropica 32: 489-501. 